\title{
Analysis of the Total Level of Flavonoids in the Brown Algae (Phaeophyceae) Extract as Analgesic and Anti-Inflammatory Drugs
}

\author{
Andi Tajrin ${ }^{1}$, Muh Hendra Chandha ${ }^{1}$, Surijana Mappangara ${ }^{1}$, Muhammad Ruslin ${ }^{1}$, Rasmidar \\ $\operatorname{Samad}^{2}(\mathbb{0}$, Fuad Husain Akbar'(D)
}

${ }^{1}$ Department Oral Surgery, Faculty of Dentistry, Hasanuddin University, Makassar, Indonesia.

${ }^{2}$ Department Dental Public Health, Faculty of Dentistry, Hasanuddin University, Makassar, Indonesia.

Author to whom correspondence should be addressed: Andi Tajrin, Department Oral Surgery, Faculty of Dentistry, Hasanuddin University, Makassar, Indonesia. Phone: +62 811 4556161. E-mail: tajrinazyes@gmail.com.

Academic Editors: Alessandro Leite Cavalcanti and Wilton Wilney Nascimento Padilha

Received: 29 July 2019 / Accepted: 11 May 2020 / Published: 08 June 2020

How to cite this article: Tajrin A, Chandha MH, Mappangara S, Ruslin M, Samad R, Akbar FH. Analysis of the total level of flavonoids in the brown algae (Phaeophyceae) extract as analgesic and anti-inflammatory drugs. Pesqui Bras Odontopediatria Clín Integr. 2020; 20:e4733. https://doi.org/10.1590/pboci.2020.103

\begin{abstract}
Objective: To determine the total level of flavonoids in brown algae extract Padina sp., Sargassum sp., and Turbinaria sp., which could serve as an analgesic and anti-inflammatory drug. Material and Methods: This is an experimental study with a one-shot case study research design. The study sample consisted of three species of brown algae, namely, Padina sp., Sargassum sp., and Turbinaria sp. The study samples were obtained from Saugi Island, Pangkep, Regency. The sampling method used was convenience sampling. The total flavonoid level in the three extracts of brown algae samples was determined at three concentrations (150 ppm, $300 \mathrm{ppm}$, and $450 \mathrm{ppm}$ ) with three replicates. The analysis used a colorimetric method, a spectrophotometer and aluminium chloride as the reagent. Results: The total level of flavonoids in Padina $s p$. was the highest at $0.894 \pm 0.027 \%$, compared to the levels of $0.786 \pm 0.075 \%$ in Sargassum sp. and 0.745 $\pm 0.016 \%$ in Turbinaria sp. Conclusion: Padina sp. had the highest total flavonoid levels compared to Sargassum sp. and Turbinaria sp. Flavonoid compounds from brown algae have the potential to be used as analgesic and anti-inflammatory drugs.
\end{abstract}

Keywords: Seaweed; Phaeophyta; Phytochemicals; Anti-Inflammatory Agents. 


\section{Introduction}

Various oral treatments, such as extraction or surgical procedures, can result in complications in the form of wounds that cause pain accompanied by inflammation. Inflammation is a protective mechanism for the body against tissue damage, but it can cause changes in physical and emotional function and reduce the quality of life [1]. The most common approach to reducing pain is the administration of analgesic drugs. Analgesic drugs usually also have the effects of being antipyretic and anti-inflammatory. Analgesic anti-inflammatory drugs are generally classified as steroids and non-steroids, which are considered more useful because they provide real analgesic and anti-inflammatory effects to reduce pain and inflammation, and are less costly than steroids [2].

Analgesic drugs are the most widely prescribed drugs in the world, although they often cause side effects. It is estimated that among users of long-term analgesic and anti-inflammatory drugs: $15-40 \%$ will have upper gastrointestinal complaints; $10-25 \%$ will suffer from peptic ulcers, especially gastric ulcers; and $1-4 \%$ will have ulcer complications that can be life-threatening, such as bleeding and perforation. To reduce the side effects from these drugs, it is necessary to find alternative analgesics and anti-inflammatory medicines with natural ingredients, mainly from plants [3].

Indonesia is a country that has a very wide sea area, and about two-thirds of the territory of the country consists of ocean. Seaweed is one of the abundant biological resources in Indonesian waters, making up approximately $8.6 \%$ of the total biota in the sea [4]. Brown seaweed is one of the natural resources of the sea, which is very abundant and generally used as a raw material in the food, cosmetics and medicine industries [5]. Phenolics are compounds that are widely found in almost all type of seaweeds, one of which is Turbinaria $s p$. They have antioxidant, anti-pyretic, analgesic, and anti-inflammatory properties [6].

In this context, this study aimed to analyse the total level of flavonoids in brown algae extracts from Padina sp., Sargassum sp., and Turbinaria sp. for possible applications as analgesic and anti-inflammatory drugs.

\section{Material and Methods}

Study Design

The research design is a one-shot case study. This study is an experimental study with a preexperimental design. It was conducted from February until April 2018 in the Phytochemical Laboratory of the Faculty of Pharmacy at Hasanuddin University. The study samples consisted of three species of brown algae, namely, Padina sp., Sargassum sp., and Turbinaria sp. The study samples were obtained from Saugi Island, Pangkep Regency. The sampling method used was a convenience sampling method.

\section{Experimental Procedures}

The procedures of this study begin with the selection of the samples to be used, washed and dried. After that, extraction of the samples was carried out by a maceration method using $70 \%$ ethanol. The total flavonoid level in the three extracts of brown algae samples was detected at three concentrations (150 ppm, $300 \mathrm{ppm}$, and $450 \mathrm{ppm}$ ) with three replicates each. The total flavonoid level was measured by a colorimetric method with a spectrophotometer and aluminium chloride $\left(\mathrm{AlCl}_{3}\right)$ as the reagent.

\section{Data Analysis}

Data were analyzed using IBM SPSS Statistics for Windows Software, version 20 (IBM Corp., Armonk, NY, USA). Descriptive statistics were used to calculate mean and standard deviation. A t-test was used with a significance level of $5 \%$. 


\section{Results}

The total flavonoid levels in Padina sp., Turbinaria sp., and Sargassum sp. are shown in Tables 1, 2 and 3 , respectively.

Table 1 shows the results of the measurement of total flavonoid levels from the Padina sp. sample at three concentrations with three replicates. At a concentration of 150,300 , and $450 \mathrm{ppm}$, the levels were 0.894 $\pm 0.027 \%, 0.567 \pm 0.043 \%$, and $0.454 \pm 0.018 \%$, respectively.

Table 1. Results of the measurement of total flavonoid levels in Padina sp.

\begin{tabular}{clccc}
\hline Concentration & Replication & Absorbance & Level (\%) & Mean (SD) \\
\hline $150 \mathrm{ppm}$ & I & 0.055 & 0.908 & $0.894 \pm 0.027$ \\
& II & 0.056 & 0.912 & \\
$300 \mathrm{ppm}$ & III & 0.045 & 0.864 & \\
& I & 0.084 & 0.518 & $0.567 \pm 0.043$ \\
& II & 0.119 & 0.595 & \\
& III & 0.117 & 0.590 & \\
& I & 0.144 & 0.433 & $0.454 \pm 0.018$ \\
& II & 0.165 & 0.464 & \\
& III & 0.166 & 0.465 & \\
\hline
\end{tabular}

Table 2 shows the results of the measurement of total flavonoid levels from the Turbinaria sp. sample at three concentrations with three replicates. At a concentration of 150,300 , and $450 \mathrm{ppm}$, the levels were $0.745 \pm 0.016 \%, 0.385 \pm 0.018 \%$, and $0.262 \pm 0.003 \%$, respectively

Table 2. Results of the measurement of total flavonoid levels in Turbinaria sp.

\begin{tabular}{clccc}
\hline Concentration & Replication & Absorbance & Level (\%) & Mean (SD) \\
\hline \multirow{2}{*}{$150 \mathrm{ppm}$} & I & 0.022 & 0.763 & $0.745 \pm 0.016$ \\
& II & 0.015 & 0.732 & \\
& III & 0.017 & 0.741 & \\
$450 \mathrm{ppm}$ & I & 0.017 & 0.370 & $0.385 \pm 0.018$ \\
& II & 0.021 & 0.379 & \\
& III & 0.033 & 0.405 & \\
& I & 0.025 & 0.259 & $0.262 \pm 0.003$ \\
& II & 0.029 & 0.264 & \\
\hline
\end{tabular}

Table 3 shows the results of the measurement of total flavonoid levels from the Sargassum sp. sample at three concentrations with three replicates. At a concentration of 150,300 , and $450 \mathrm{ppm}$, the levels were $0.786 \pm 0.075 \%, 0.407 \pm 0.022 \%$, and $0.287 \pm 0.055$, respectively.

Table 3. Results of the measurement of total flavonoid levels in Sargassum sp.

\begin{tabular}{ccccc}
\hline Concentration & Replication & Absorbance & Level (\%) & Mean (SD) \\
\hline \multirow{2}{*}{$150 \mathrm{ppm}$} & I & 0.015 & 0.732 & $0.786 \pm 0.075$ \\
& II & 0.047 & 0.872 & \\
& III & 0.020 & 0.754 & \\
$400 \mathrm{ppm}$ & I & 0.039 & 0.419 & $0.407 \pm 0.022$ \\
& II & 0.040 & 0.421 & \\
& III & 0.022 & 0.381 & \\
& I & 0.050 & 0.295 & $0.287 \pm 0.055$ \\
& II & 0.049 & 0.294 & \\
& III & 0.035 & 0.273 & \\
\hline
\end{tabular}


Table 4 shows the total flavonoid level in the samples of Padina sp., Turbinaria sp., and Sargassum sp. at each measured concentration. Figure 1 shows that Padina sp. had the highest level of total flavonoid at each concentration, followed by Sargassum sp. and then Turbinaria sp. Based on their concentrations, the three samples had the highest to lowest total flavonoid levels from 150 to 300 to $450 \mathrm{ppm}$.

Table 4. Total flavonoid levels in all three samples at each concentration.

\begin{tabular}{cccc}
\hline Concentration & \multicolumn{3}{c}{ Total Flavonoid Level (\%) } \\
& Padina sp. & Turbinaria sp. & Sargassum sp. \\
\hline $150 \mathrm{ppm}$ & $0.894 \pm 0.027$ & $0.745 \pm 0.016$ & $0.786 \pm 0.075$ \\
$300 \mathrm{ppm}$ & $0.567 \pm 0.043$ & $0.385 \pm 0.018$ & $0.407 \pm 0.022$ \\
$450 \mathrm{ppm}$ & $0.454 \pm 0.018$ & $0.262 \pm 0.003$ & $0.287 \pm 0.055$ \\
\hline
\end{tabular}

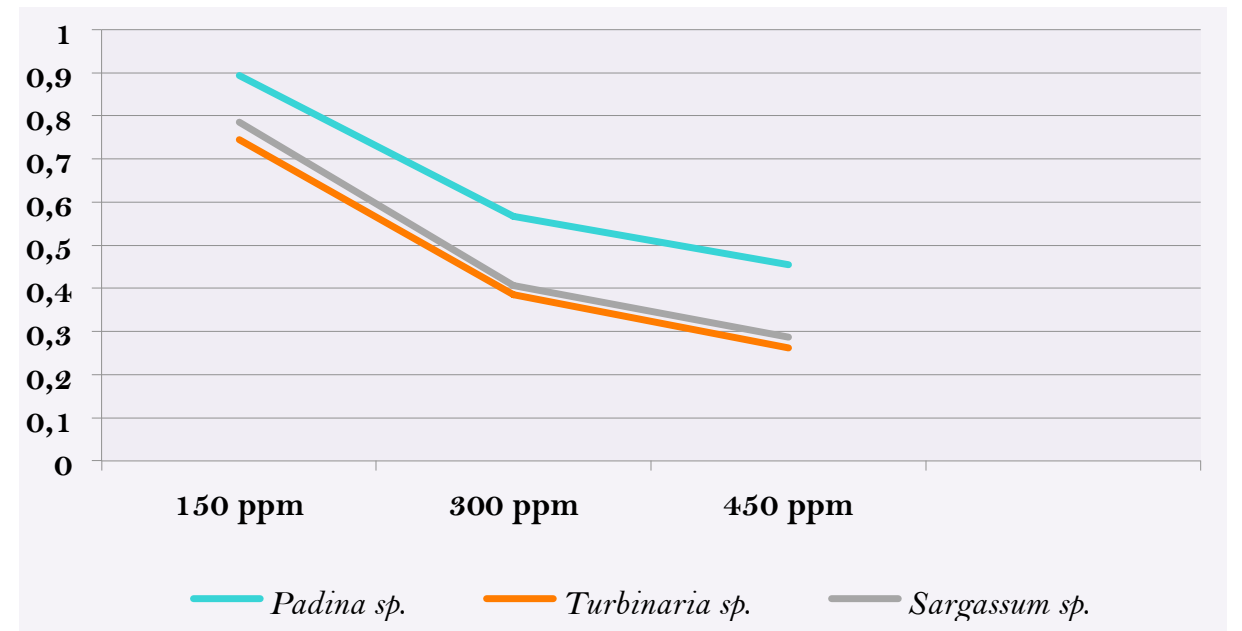

Figure 1. Comparison of the average levels of each of the samples at each concentration.

\section{Discussion}

The extraction procedures used a maceration method and $70 \%$ ethanol. The advantages of a maceration method are that it uses simple equipment, is relatively inexpensive, and can avoid heat damage to the active compound components in the sample [7,8]. There are various types of solvents that can be used for the extraction of flavonoids from brown algae samples. Although when selecting a solvent, you need to consider the polarity of the compound. The extraction method and type of solvent used did not affect the flavonoid content in these samples. This is because flavonoids tend to have balanced polar and non-polar group and their extraction does not depend on the type of solvent used [9].

The total flavonoid level was measured by a colorimetric method using a spectrophotometer and aluminium chloride $\left(\mathrm{AlCl}_{3}\right)$ as a reagent. Colorimetric method can be used to identify and quantify all flavonoids in propolis using aluminium chloride or 2,4-dinitro-phenylhydrazine reagents, which form stable complexes with flavonoid compounds [10].

In this study, the measurement results showed that Padina sp., Sargassum sp., and Turbinaria sp have effective anti-inflammatory and analgesic activities based on the flavonoid compounds they contained. Brown algae Padina sp. and Sargassum sp. taken from Saugi Island, Pangkep, Regency, can reduce inflammatory levels in mice, suggesting they can be used as sources of anti-inflammatory agents [8]. Also, Sargassum swartzii (Turner), C. agardh (Phaeophyta), and Ulva reticulate Forsskal (Chlorophyta) algae have been tested in animal 
models. This study showed that a $500 \mathrm{mg} / \mathrm{kg}$ body weight both the $S$. swartzii and U. reticula extracts induced a protective analgesic effect against both thermal stimuli and writhing syndrome, showing central and peripheral effects. In addition, this study also showed that a methanolic extract of $S$. swartzii had antiinflammatory effects on both acute (exudative) and chronic (proliferative) inflammation [6]. The study results are supported by various pharmacological studies conducted on algae showing that the chemical compounds produced by marine algae have different biological activities, such as anti-inflammatory, anticancer, anti-HIV, anti-mutagenic, and antioxidant properties [11].

The higher total flavonoid level in Padina sp. suggests more effective anti-inflammatory and analgesic activities than Sargassum sp. and Turbinaria sp. The content of flavonoid compounds in the Padina sp. extract were higher than in the Sargassum sp. extract and they have the potential to be used as analgesic drugs [9]. Various types of flavonoids significantly affect the function of the immune system and inflammatory cells. The clinical effects of flavonoids are based on inhibitory mechanisms on prostaglandin in the central and peripheral nervous system. Prostaglandin is produced from arachidonic acid by cyclooxygenase-1 and -2 , and it plays an important role in pain and inflammation.

Flavonoids can also specifically affect the function of enzyme systems that are involved in the inflammation process, specifically tyrosine and serine-threonine protein kinases [12,13]. In the peripheral nervous system, the analgesic activities of flavonoids play a role in increasing opioid peptide levels and decreasing the secretion of substances that cause pain, which is related to the inflammatory mediators by reducing the release of nitric oxide (NO), PGE2, and pro-inflammatory cytokines, as well as increasing the release of IL-10. Whereas in the central nervous system, the analgesic activities of flavonoid compounds play specific roles in removing opioid receptors and increasing opioid peptide levels, inhibiting the central calcium channels, inhibiting the synthesis of prostaglandins, and facilitating the release of NO in brain tissue [14].

The study's limitations are that further research needs to be conducted using brown algae with Padina $s p$ and Sargassum sp in order to compare their levels of flavonoids to that of Turbinaria sp.

\section{Conclusion}

Padina sp. had the highest total flavonoid levels compared to Sargassum sp. and Turbinaria sp. Flavonoid compounds from brown algae have the potential to be used as analgesic and anti-inflammatory drugs. However, further research is needed before they can be applied to humans.

\section{Authors' Contributions}

\begin{tabular}{|c|c|c|}
\hline AT & (iD) $0000-0002-4186-7968$ & $\begin{array}{l}\text { Conceptualization, Methodology, Formal Analysis, Validation, Resources, Writing } \\
\text { - Review and Editing and Supervision. }\end{array}$ \\
\hline MHC & (iD) $0000-0001-6291-9766$ & Formal Analysis, Resources and Writing - Review and Editing. \\
\hline $\mathrm{SM}$ & (iD) $0000-0002-4215-6412$ & Formal Analysis and Writing - Review and Editing. \\
\hline MR & (iD) $0000-0003-0943-4000$ & $\begin{array}{l}\text { Investigation, Validation, Resources, Formal Analysis and Writing - Review and } \\
\text { Editing. }\end{array}$ \\
\hline $\mathrm{RS}$ & (iD) $0000-0002-1384-6967$ & Investigation, Resources, Validation and Formal Analysis. \\
\hline FHA & (iD) $0000-0003-4819-4820$ & $\begin{array}{l}\text { Methodology, Investigation, Formal Analysis, Data Curation and Writing - } \\
\text { Original Draft Preparation. }\end{array}$ \\
\hline
\end{tabular}

\section{Financial Support}

None. 


\section{Conflict of Interest}

The authors declare no conflicts of interest.

\section{References}

[1] Yusuf Y, Yuliastuti, Sumastuti R. Efek analgesik ekstrak daun makutadewa (Phaleria macrocarpa) pada mencit. J Bionature 2013; 14(1):1-6. https://doi.org/10.35580/bionature.v 14i1.1440 [In Indonesian]

[2] Wibisono G. NSAID: Dari analgetik-antiinflamasi ke antineoplasi. JKGUI 2002; 9(2):23-9. https://doi.org/10.14693/jdi.v9i2.677 [In Indonesian]

[3] Setyari W, Sudjarwo SA. Potensi analgesik dan antiinflamasi dari ekstrak tapak liman (Elephantophus scraber). J Penelit Med Eksakta 2008; 7(1):16-22. [In Indonesian]

[4] Suparmi, Sahri A. Mengenal potensi rumput laut: kajian pemanfaatan sumber daya rumput laut dari aspek industri dan kesehatan. Sultan Agung 2008; 44(118):95-116. [In Indonesian]

[5] Limantara L, Heriyanto H. Optimasi proses ekstraksi fukosantin rumput laut coklat padina australis hauck menggunakan pelarut organik polar. Ilmu Kelautan 2011; 16(2):86-94. https://doi.org/10.14710/ik.ijms.16.2.86-94 [In Indonesian]

[6] Hong DD, Hien HM, Anh HTL. Studies on the analgesic and anti-inflammatory activities of Sarrgassum swartzii (Turner) C. Agardh (Phaeophyta) and Unlva reticulate Forsskal (Chlorophyta) in experiment animal models. Afr J Biotechnol 2011; 10(12):2308-14. https://doi.org/10.5897/AJB10.213

[7] Untari EK, Wahdaningsih S, Damayanti A. Effect of Hylocereus polyrhizus n-hexane skin fraction on catalase activity of rat oxidative stress. Pharm Sci Res 2014; 1(3):141-53. https://doi.org/10.7454/psr.v1i3.3489

[8] Asmawati A, Hasyim R, Lianingsih AIA, Ariani DF. The difference of anti-inflammatory effect of brown algae extract panida sp and sargassum sp that is derived from punaga beach, south sulawesi. J Dentomaxillofac Sci 2016; 1(2):1169. https://doi.org/10.15562/ jdmfs.v1i2.8

[9] Ruslin M, Akbar FH, Hajrah YA, Subehan S. Analysis of total flavonoid levels in brown algae (Sargassum sp. and Padina sp.) as analgesic drug therapy. Asian J Pharm Clin Res 2018; 11(7):81-3. https://doi.org/10.22159/ajpcr.2018.v11i7.25657

[10] Chang CC, Yang MH, Wen HM, Chern JC. Estimation of total flavonoid content in propolis by two complementary colorometric methods. J Food Drug Anal 2002; 10(3):178-82.

[11] Vijayan H, Mathew L. Evaluation of phytochemical constituents of two different species of turbinaria. Int J Sci Res 2017; 6(7):224-6. https://doi.org/10.36106/ijsr

[12] Kumar S, Pandey AK. Chemistry and biological activities of flavonoids: an overview. Scientific World Journal 2013; 2013:162750. https://doi.org/10.1155/2013/162750

[13] Rafieian-Kopaei M, Shakiba A, Sedighi M, Bahmani M. The analgesic and anti-inflamatory activity of Linum usitatissimun in balb/c mice. J Evid Based Complement Altern Med 2017; 22(4); 892-6. https://doi.org/10.1177/2156587217717416

[14] Xiao X, Wang X, Gui X, Chen L, Huang B. Natural flavonoids as promising analgesic candidates: a systematic review. Chem Biodivers 2013; 13(11):1427-40. https://doi.org/10.1002/cbdv.201600060 